\title{
Treatment of Chronic Back and Chest Pain in a Patient with Sickle Cell Disease Using Spinal Cord Stimulation
}

\author{
Orak Hücre Hastasında Kronik Sırt ve Göğüs Ağrısının Spinal Kord Stimülatörü ile Tedavisi
}

\author{
(D) Damla Yürük1, (D) ibrahim Aşık² \\ ${ }^{1}$ Bursa Yüksek Ihtisas Training and Research Hospital, Clinic of Algology, Bursa, Turkey \\ ${ }^{2}$ Ankara University Faculty of Medicine, Department of Algology, Bursa, Turkey
}

To the Editor,

Pain with sickle cell disease can occur in two forms: acute or chronic. Acute pain is often treated with analgesics in emergency services or at home and can intermittently relapse. In the later stages of the disease, chronic pain occurs due to central sensitization. Here we report a patient with sickle cell pain who was treated with a spinal cord stimulator (SCS).

Our patient was a 28 -year-old female. She was admitted to the hospital due to painful crises and had a history of operations due to vertebral fracture, femoral head osteonecrosis, and pulmonary hypertension. Her back and chest pain was ranked as 9 on a numeric rating scale when she was referred to the pain clinic. Non-enhancing areas involving vertebral bodies at dorsal and lumbar levels, suggestive of infarcts, were shown by magnetic resonance imaging (Figure 1). Pain control could not be achieved medically; all nonsteroidal anti-inflammatory drugs and opioids had been unsuccessful. After evaluation by the local pain council of the hospital, the patient underwent implantation of an SCS.

In the operating room she was placed in the prone position. Under fluoroscopic guidance a 15-gauge Tuohy needle was inserted into the T6-T7 interlaminar space. Eight-electrode leads were inserted through the needle and advanced until the tip lay at the T1-T4 epidural level (Figure 2). Parameters of stimulation were pulse width of amplitude $2.5 \mathrm{~mA}$ and frequency of $10 \mathrm{kHz}$. Following more than $60 \%$ pain relief throughout the trial period, the lead was connected to an implantable pulse generator, which was placed into the left buttock. During 1-year follow-up of the implantation of the high-frequency SCS, excellent pain relief continued with improvement of both the patient's pain and her ability to perform activities of daily living.

SCS has become popular in recent years. It is a neuromodulator and manages cases of certain chronic pain for which other procedures have failed, including failed back syndrome [1], ischemic limb pain [2], angina pectoris [3], and painful peripheral

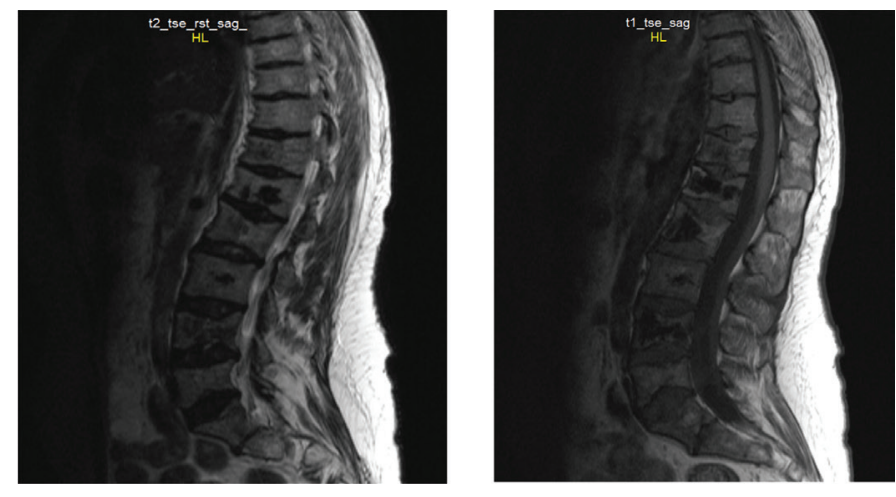

Figure 1. Magnetic resonance imaging shows multiple infarcts involving vertebral column T2 and T1 sagittal images. Nonenhancing areas involving vertebral bodies at dorsal and lumbar levels suggest infarcts.
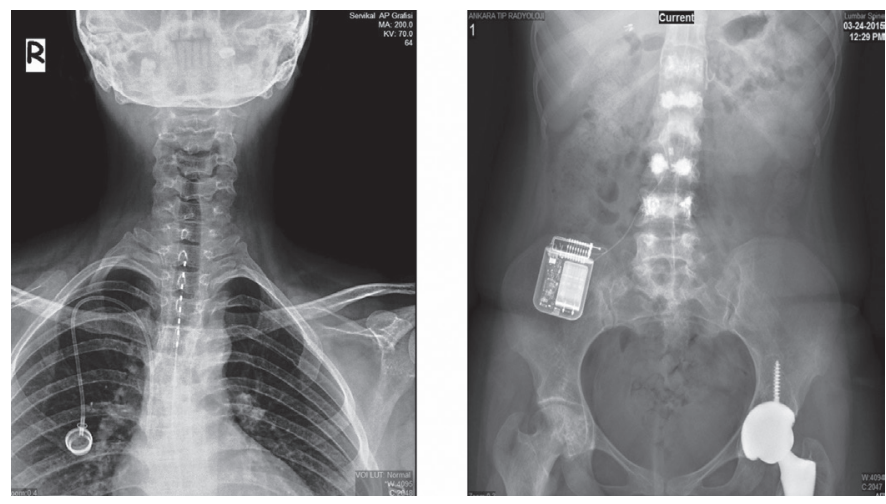

Figure 2. Plain X-ray demonstrating placement of spinal cord stimulator electrodes at the level of T1-T4.

neuropathies [4]. The mechanism of pain relief by the SCS is still not clear [5]. According to the gate control theory, in the peripheral nerve system the afferent activity of large fibers or small fibers is controlled by the dorsal column cells, associated with central transmission of pain. When a surplus of large-fiber activity occurs, this gate closes [6]. The pathophysiology of sickle cell disease could also be related to autonomic nervous system efficiency [7]. Constriction or obstruction of a blood vessel usually causes a reduction in blood flow and oxygen delivery to the tissues and thus insufficient perfusion [8]. Small 
fibers, which carry nociceptive information in the sympathetic pain pathway, can be blocked by a high-frequency SCS.

The present report describes the first patient with intractable pain due to sickle cell disease who was treated with a highfrequency SCS successfully. For patients in whom all available treatments have failed or who have an increased risk for more invasive surgical interventions, the SCS might be a therapeutic alternative.

Keywords: Chronic pain, Sickle cell disease, Spinal cord stimulation

Anahtar Sözcükler: Kronik ağrı, Orak hücre hastalığı, Spinal kord stimülatörü

Informed Consent: It was received.

Conflict of Interest: The authors of this paper have no conflicts of interest, including specific financial interests, relationships, and/ or affiliations relevant to the subject matter or materials included.

\section{References}

1. Kumar K, Hunter G, Demeria D. Spinal cord stimulation in treatment of chronic benign pain: challenges in treatment planning and present status, a 22-year experience. Neurosurgery 2006;58:481-496.

2. Ghajar AW, Miles JB. The differential effect of the level of spinal cord stimulation on patients with advanced peripheral vascular disease in the lower limbs. Br J Neurosurg 1996;12:402-408.

3. Hautvast RW, DeJongste MJ, Staal MJ, van Gilst WH, Lie KI. Spinal cord stimulation in chronic intractable angina pectoris: a randomized controlled efficacy study. Am Heart J 1998;136:1114-1120.

4. Kumar K, Toth C, Nath RK. Spinal cord stimulation for chronic pain in peripheral neuropathy. Surg Neurol 1996;46:363-369.

5. Melzack RA, Wall PD. Pain mechanisms: a new theory. Science 1965;150:971979.

6. Stojanovic M, Abdi S. Spinal cord stimulation. Pain Physician 2002;5:156166.

7. Nebor D, Bowers A, Hardy-Dessources MD, Knight-Madden J, Romana $M$, Reid $H$, Barthélémy JC, Cumming $V$, Hue 0 , Elion J, Reid $M$, Connes $P$; CAREST Study Group. Frequency of pain crises in sickle cell anemia and its relationship with the sympatho-vagal balance, blood viscosity and inflammation. Haematologica 2011;96:1589-1594.

8. Simpson EL, Duenas A, Holmes MW, Papaioannou D, Chilocott J. Spinal cord stimulation for chronic pain of neuropathic or ischaemic origin: systematic review and economic evaluation. Health Technol Assess 2009;13:1-154.

๑Copyright 2018 by Turkish Society of Hematology

Turkish Journal of Hematology, Published by Galenos Publishing House

\title{
Simultaneous Presence of Follicular Lymphoma, Diffuse Large B-cell Lymphoma, and Hodgkin-like Lymphoma
}

\section{Eş Zamanlı Folliküler Lenfoma, Diffüz Büyük B Hücreli Lenfoma ve Hodgkin-Benzeri Lenfoma Varlığı}

(D) Alexandra Papoudou-Bai1, (D) Leonidas Marinos², (D) Konstantina Papathanasiou4, (D) Panagiotis Kanavaros³, (D) Eleni Kapsali4

\author{
1 University of loannina Faculty of Medicine, Department of Pathology, loannina, Greece \\ 2Evangelismos General Hospital, Clinic of Hematopathology, Athens, Greece \\ 3 University of loannina Faculty of Medicine, Department of Anatomy-Histology-Embryology, loannina, Greece \\ 4University of loannina Faculty of Medicine, Department of Hematology, loannina, Greece
}

To the Editor,

Follicular lymphoma (FL) is a relatively indolent B-cell lymphoma that may transform to a higher-grade lymphoma, most commonly diffuse large B-cell lymphoma (DLBCL) [1]. On the other hand, the occurrence of Hodgkin lymphoma $(\mathrm{HL})$ subsequent to $\mathrm{FL}$ as well as composite lymphomas that are composed of $\mathrm{HL}$ and $\mathrm{FL}$ have rarely been recorded $[1,2,3,4,5]$. To the best of our knowledge, this is the first reported case of the simultaneous presence of $\mathrm{FL}, \mathrm{DLBCL}$, and Hodgkin-like lymphoma in a lymph node. A 65-year-old man developed a palpable mass in his left axilla, which grew larger in a period of 2 months. The patient reported no other symptoms and had no notable medical history. Biopsy of the left axillary lymph node revealed grade 3A-FL with areas of DLBCL. DLBCL was also observed in the biopsy of a mass of the thoracic wall, which was near the enlarged axillary lymph node. Moreover, in the lymph node, Hodgkin and Reed-Sternberg (HRS) cells were identified in extrafollicular areas and some neoplastic follicles (Figure 1). Although some scattered eosinophils, plasma 